\title{
Business process modeling for processing classified documents using RFID technology
}

\author{
Jarosław Koszela ${ }^{1, a}$ \\ ${ }^{1}$ Military University of Technology, Faculty of Cybernetics, Institute of Computer and Information Systems, Warsaw, Poland
}

\begin{abstract}
The article outlines the application of the processing approach to the functional description of the designed IT system supporting the operations of the secret office, which processes classified documents. The article describes the application of the method of incremental modeling of business processes according to the BPMN model to the description of the processes currently implemented ("as is") in a manual manner and target processes ("to be"), using the RFID technology for the purpose of their automation. Additionally, the examples of applying the method of structural and dynamic analysis of the processes (process simulation) to verify their correctness and efficiency were presented. The extension of the process analysis method is a possibility of applying the warehouse of processes and process mining methods.
\end{abstract}

Keywords: business process modeling, BPMN, RFID, Classified Registry/secret office, workflow system, business process simulation, warehouse of processes, process mining

\section{Introduction}

At the time of building IT systems supporting the operations of an organization, it is essential to apply the methods and tools which allow to determine the needs and functions of the system for the purpose of mitigating the risk of its failure and more precise assessment of the system's complexity and cost. The article outlines the application of the processing approach to the description of the functionality of the secret office in organization. The example describes the business process modeling method from the current state (manual processes) to the target state (automated processes using the RFID technology [1], [2]) and the use of the tool for structural and dynamic process analysis (business process simulation, warehouse of process, process mining).

The application of the RFID (Radio-Frequency Identification) technology for processing the documents with different sensitivity levels was caused by insufficient level of protection of sensitive documents and the process of handling such documents, which are currently implemented. The application of RFID increases the level of security of the documents as well as the efficiency of their processing and flows in the secret office and other organizations, where the document archiving and workflow are crucial for their functioning. Since such solutions are rather complex and consist of many different components, which differ in terms of technology and the scope of their functioning and impact [3] (i.e. IT, ICT, electronic, mechanical, organizational,

\footnotetext{
a Corresponding author: jkoszela@wat.edu.pl
}

formal and legal systems), it is required to apply the method for describing the system's functionalities and their analysis.

Therefore, the objective is to verify a possibility of modeling main activities performed in the secret office in the traditional form (without automation) and when using process automation systems, including ICT systems (workflow system [4], [5], [6], registers and date resources [7], [8]), RFID technology and a possibility of checking their compliance with the BPMN [9] model, also by applying the process simulation method.

\section{Business processes modeling - phases of life cycle}

The PDCA model [10] may be used to manage business processes in organization. The model describes the life cycle of the process and consists of the four main steps (Figure 1): Plan, Do, Check, Act. The model presents a closed cycle of the process management, where the processes should be constantly modified and improved. 


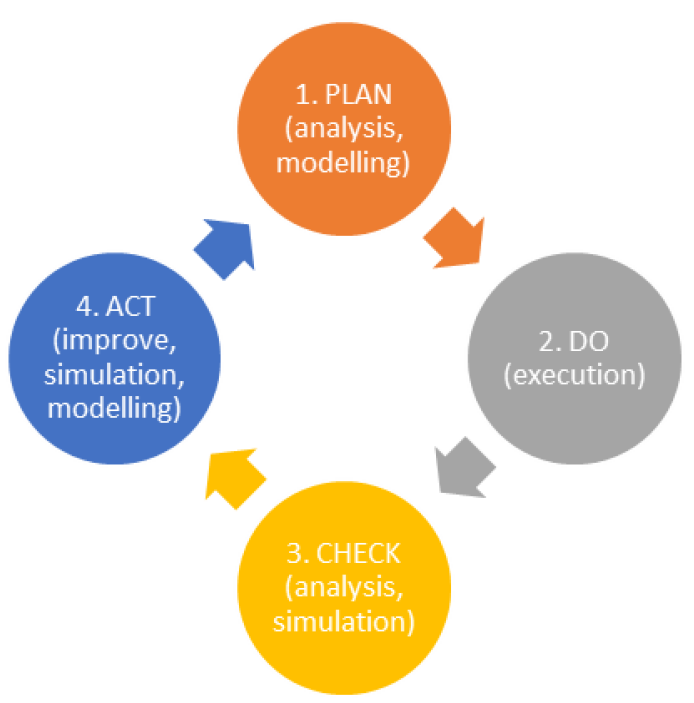

Figure 1. PDCA - life cycle of business process

The modeling of the business processes according to BPMN for the secret office in the operating organization may be divided into two main phases (Figure 2) [11], [12]: modeling of the processes that are currently implemented in the organization ("as is") and modeling of the processes for the target model of the organization's functioning model ("to be"). It means that the change of the current processes to target processes must be defined by determining which mainly business goals are to be achieved (e.g. increasing efficiency of the organization's operations, decreasing the costs, reducing the execution time, increasing safety, etc.).

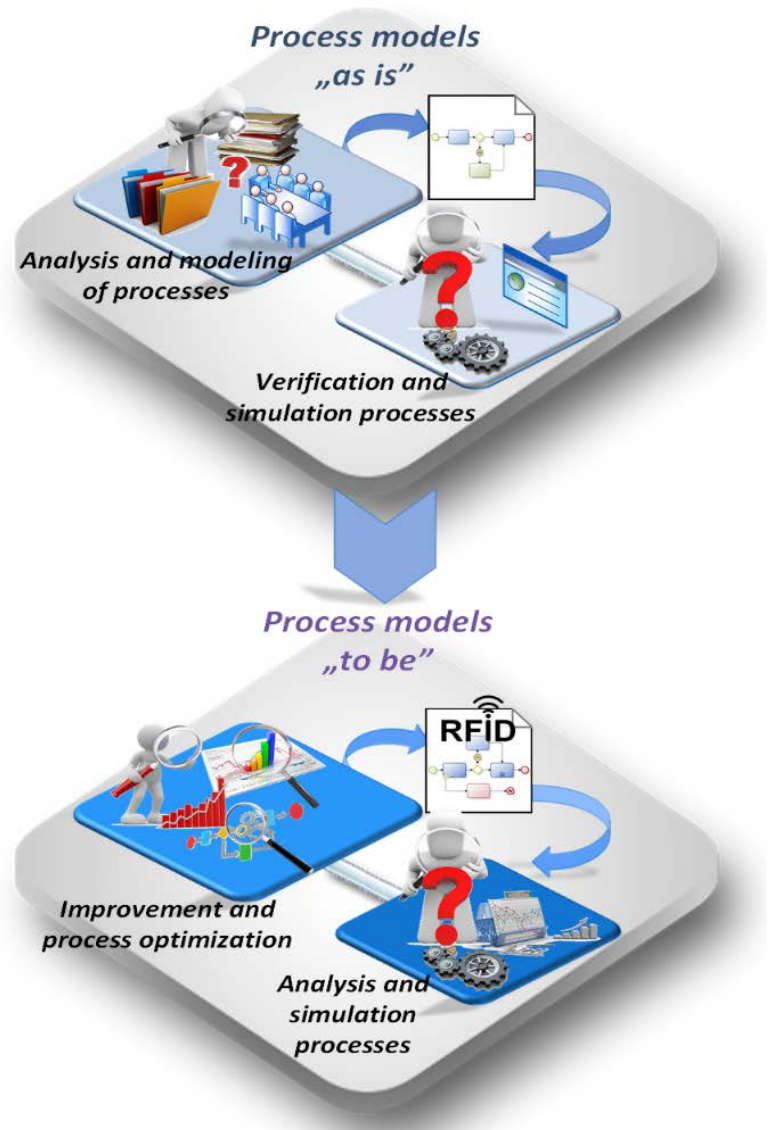

Figure 2. Modeling processes from « as is » to « to be » phase
The developed processes may be used for their automation by applying the process automation system (i.e. workflow process) as well as for the analysis and exploration of the processes (Figure 3) [5], [6], [13].

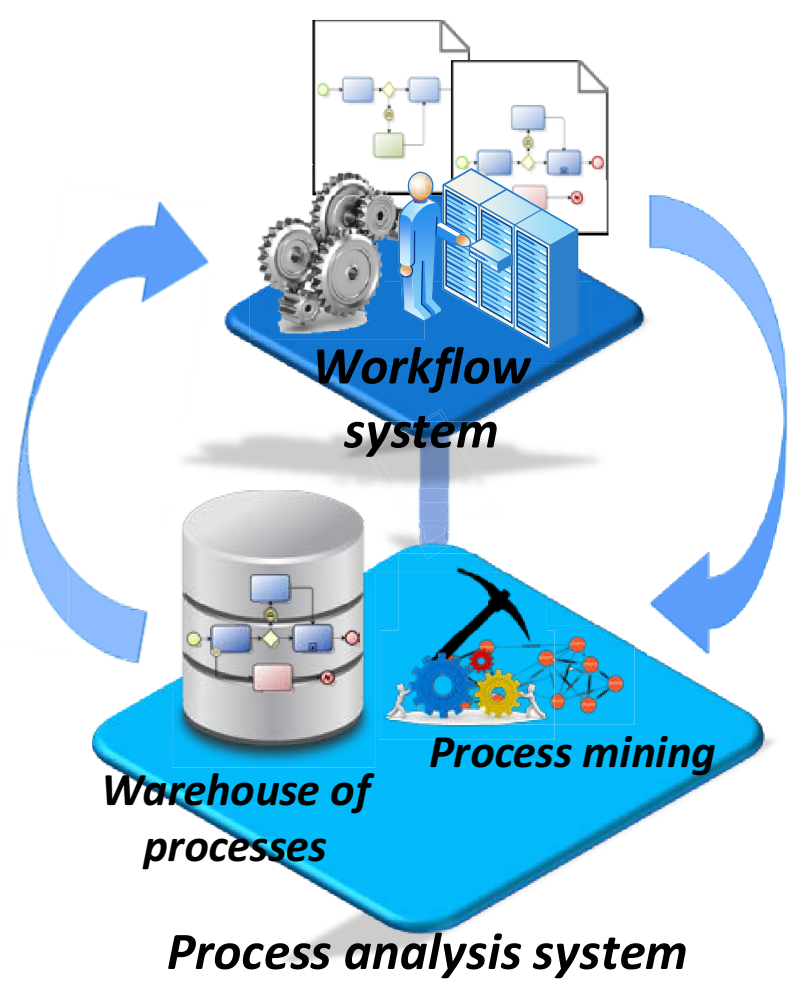

Figure 3. Execution (workflow system) and analysis ( process system architecture

The main function of the warehouse of processes and process mining, being one of the tools supporting the decision-making process, is a possibility of conducting analyses of the collected resources, such as [13]:

- in the area of the process definition analysis:

1) suggesting model definitions of the processes during the modeling based on the already used elements of the process and set of models,

2) semantic similarity measures of the process definition or fragments thereof,

3) structural similarity measures of process definition or fragments thereof,

4) validation of the correctness of the process definition by analyzing the graph created on the basis of this definition,

5) analysis of the construction of the process definition by analyzing the graph created on the basis of this definition,

6) the level of detail of the definition defined as: readability - the number of vertices of a single graph and component subgraphs, complexity - the number of resources assigned to the graph or component graph,

7) determination whether a gridlock may occur when two activities are mutually waiting for their completion,

8) including all cases in the definition, 
- in the area of the process implementation analysis (instances):

a) process mining: discovering new process definitions based on the instance of the process execution, execution deviations from the process definition, searching for models and their rare and common sequence of events;

b) quantitative analyses: execution time, delays, use of resources, how many instances can be appointed within an hour, what is the average flow time, how many additional resources may be needed, how many particular types of resources are consumed during working days, similarity measures of the sequence of events, analysis of the adequacy of the process in a ratio (whether the given process in effect gives the expected results), identification of problems (e.g. congestion) and their causes.

\section{Business processes of the secret office}

The operations of the secret office (SO), which is by nature responsible for processing classified documentation, include many processes related to the document flow. The developed processes are in compliance with applicable Polish law. The basic processes in the form of the process hierarchy were presented below:

\section{- A Acceptance of the parcel}

- A1 Registration of the correspondence received in the secret office,

- A2 Acceptance of the parcel which was damaged/bears traces of opening,

- B Creation of the material,

- B1 Confidentiality clause,

- B2 Registration of the created material,

- B3 Storage,

○ B3.1 Destruction of the cryptographic material,

- B3.2 Sending of the material via carrier with sub-process B3.2.1 Explanation of failure in delivery of the parcel,

- B3.3 Receipt of the request to share the document and sub-process: B3.3.1 Sharing of the material, B3.3.1.1 Return of the material,

- B3.4 Inventory (stocktaking),

- C Issuance of Cryptographic Access Certificate

- C1 Storage of the Certificate,

- C1.1 Issuance of the Certificate for the working purposes,

- C1.2 Cancellation of the Certificate,

\subsection{Business process model - phase "as is"}

Figure 4 shows the business process model for making the documents available in the secret office in the "as is" phase. The process describes legitimate activities that are performed manually, without any IT systems or RFID, for the purpose of their automation.

The structural and dynamic analyses of the developed processes were also conducted in this phase. The dynamic analysis of the processes was based on the process simulation, including the parameters estimated during the sample analysis of the secret office. According to the general analysis, it is evident that the "as is" phase covers 41 business processes, which include over: 240 processes/sub-processes, 75 gateways and 160 events.

The Bizagi Modeler v2.9 [14] software was used to model business processes according to BPMN v2.0 and simulate the processes according to BPSim v1.0.

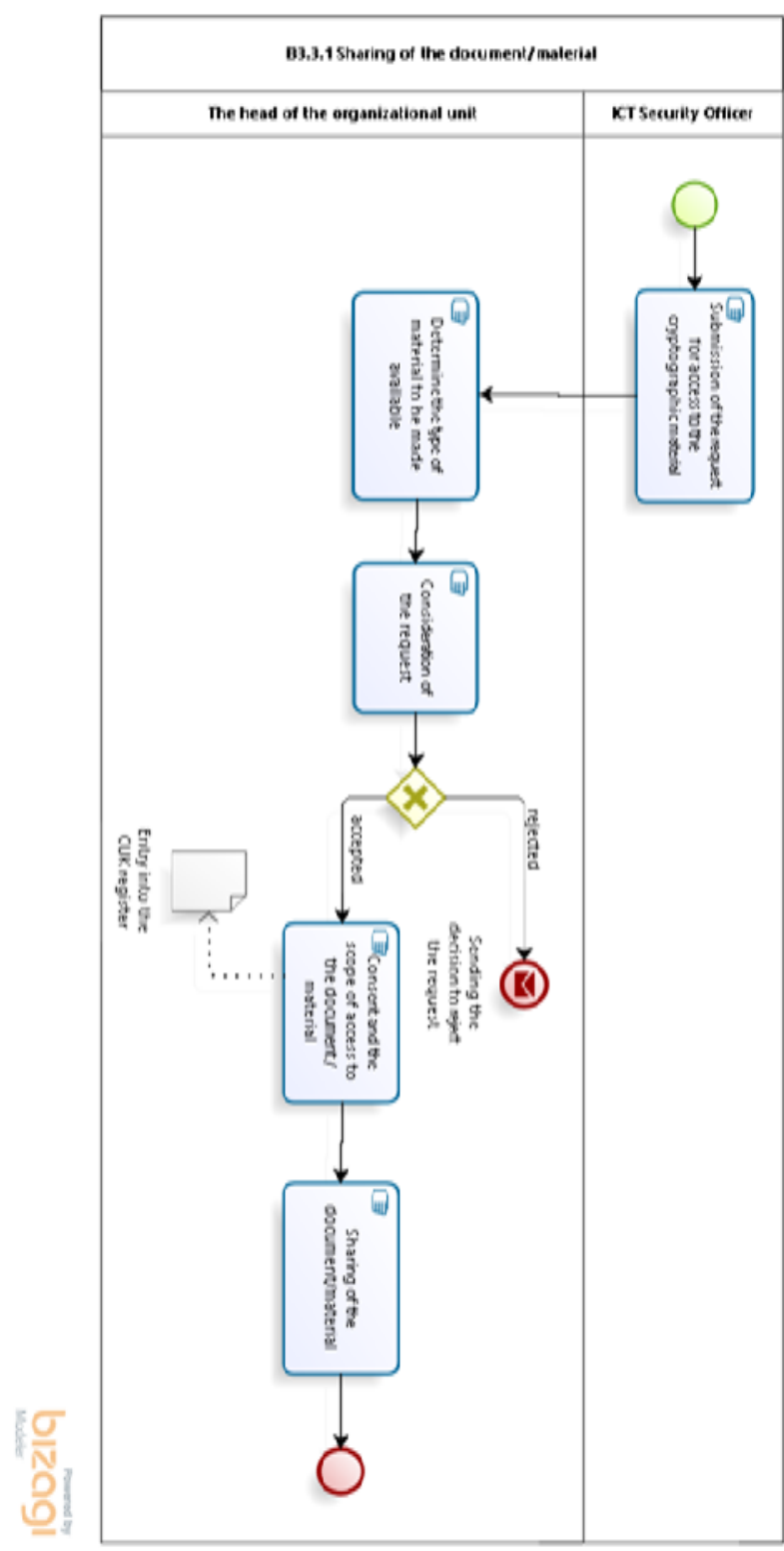

Figure 4. BPMN process: Sharing of the document - phase "as is" 


\subsection{Business process model - phase "to be"}

Figure 5 shows the business process model for making the documents available in the secret office, using RFID and IT systems - phase "to be". The developed models in the "to be" phase extend the functionality of the "as is" phase by incorporating actions with the use of the RFID technology and include a possibility of work in case of failure of the IT and RFID systems.

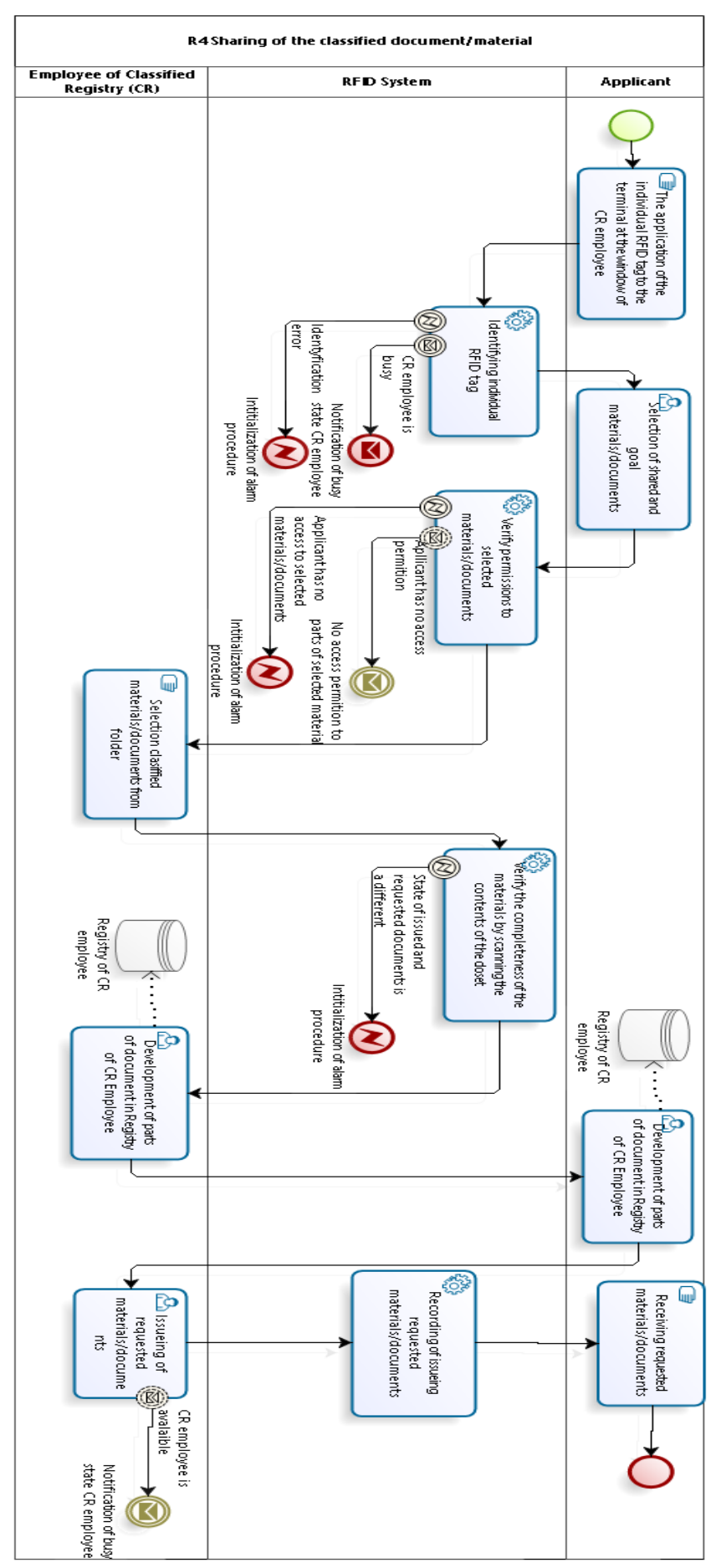

Figure 5. BPMN process: Sharing document with RFID- phase "to be"
Similarly to the business process models of the "as is", the structural and dynamic analysis of the business process models of the "to be" phase was performed. In this phase, 66 business processes were performed, in which over: 390 processes/sub-processes, 169 gateways, 288 events were applied.

The process simulation was used to verify changes resulting from the application of the RFID technology in the secret office in the modeled processes. The test included estimation of the execution time necessary for one case in the discussed processes. The results of the simulation showed that the estimated average time of execution of the availability process performed using the traditional method was 31 min., whereas in case of the RFID-supported process - the time was shorter by half, i.e. $15 \mathrm{~min}$. When bearing in mind the 8-hour working time in the secret office, it is apparent that the technology should increase the efficiency and quality of handling the matters in the SO, including high reliability of the whole supporting system, using the RFID technology.

\section{Conclusion}

The availability of the new technologies contributes to their wide spreading in many different institutions. The application of the RFID technology in the processes of the secret office not only improved the functioning of the entire office, but also ensured better protection of the materials stored therein. Furthermore, the work capacity improved, which was demonstrated in the simulation. Nonetheless, it should be remembered that such systems are not $100 \%$ reliable. To avoid a situation, when the secret office is obliged to discontinue its operations due to failed technology, an alternative way of implementing the processes should be always available. In such case, it is worth using the process implemented in a traditional manner, which is in accordance with the effective legal standards.

The RFID technology offers cost-effective means of electronically tagging documents while maintaining remote identification capabilities. Moreover the utilization of such technology provides more convenient ways to organize and tag documents in comparison with QR codes. The simplicity of RFID scanning process and the possibility of faster and more accurate, close range object identification, makes the technology more convenient for large document storages.

The RFID system, as every other technology, ceases to meet the expectations with time, therefore, it is worth continuing further research to find other types of systems for the management and handling of the office processes so that the information contained in the sensitive documents is not disclosed to any unauthorized parties.

The analysis of the processes as the definition and implemented instances constitute the further direction of the research. Their analysis by developing different methods and tools will allow, for example [13]: to define trends, similarities and anomalies, and by applying the feedback method in the process of building the systems using the process approach, it is possible to improve the 
quality and efficiency of the implemented processes in the automated ICT environment.

\section{References}

1. V. D. Hunt, A. Puglia i M. Puglia, RFID-A guide to radio frequency identification, Hoboken, New Jersey: John Wiley \& Sons, Inc. (2007)

2. S. Edwards i M. Fortune, A Guide to RFID in Libraries, London: Book Industry Communication (2008)

3. M. Kiedrowicz, Zarzadzanie informacjami wrażliwymi - wybrane aspekty organizacyjne, prawne i techniczne ochrony informacji niejawnych, Warszawa, WAT, (2015)

4. M. Weske, Business Process Management. Concepts, Languages, Architectures, Berlin, Springer-Verlag (2007)

5. B. Gawin, Systemy informatyczne $w$ zarzadzaniu procesami Workflow, Warszawa, PWN (2015)

6. W. van der Aalst i K. van Hee, Workflow Management. Models, Methods, and Systems, Massachusetts London, The MIT Press Cambridge (2002)
7. M. Kiedrowicz, Organizacja i dostęp do heterogenicznych, publicznych zasobów danych, Projektowanie systemów informatycznych: modele $i$ metody, Warszawa, WAT (2014)

8. M. Kiedrowicz, Rejestry i zasoby informacyjne wykorzystywane przez organy odpowiedziane za wykrywanie i przeciwdziałanie przestępczości, Jawność i jej ograniczenia: Zadania i kompetencje, Warszawa, C.H.Beck Sp. z o.o. (2015)

9. OMG, BPMN - standard documents. [Online] http://www.omg.org/spec/BPMN/2.0/ (2011)

10. R. Moen i C. Norman, Evolution of the PDCA Cycle (2009)

11. A. Arsanjani, N. Bharade, M. Borgenstrand, P. Schume, J. K. Wood i V. Zheltonogov, Business Process Management Design Guide. Using IBM Business Process Manager, USA, IBM Corporation (2015)

12. A. Sidnev, J. Tuominen i B. Krassi, Business Process Modeling and Simulation, Espoo, Otamedia Oy (2005)

13. G. Bliźniuk, M. Chmielewski, T. Gzik i J. Koszela, Warehouse of processes, Studia Informatica, 33-2A, 111-127 (2012)

14. Bizagi, [Online] http://www.bizagi.com (2016) 